\title{
Status of Ashy Storm-Petrel breeding colonies at Santa Cruz Island, California, 1912-1998
}

\author{
Harky R. Carter $1,2, \dagger$, William R. McIver $1,3, *$, Gerard J. McChesney 1,4 , \\ Darrell L. Whitworth ${ }^{1,5}$, and John R. Gilardi ${ }^{1,6}$ \\ ${ }^{1}$ Humboldt State University, Department of Wildlife, 1 Harpst St., Arcata, CA 95521 \\ ${ }^{2}$ Recent address: Carter Biological Consulting, 1015 Hampshire Road, Victoria, BC V8S4S8, Canada \\ ${ }^{3}$ Present address: U.S. Fish and Wildlife Service, Arcata Fish and Wildlife Office, 1655 Heindon Road, Arcata, CA 95521 \\ ${ }^{4}$ Present address: U.S. Fish and Wildlife Service, San Francisco Bay National \\ Wildlife Refuge Complex, 1 Marshlands Road, Fremont, CA 94555 \\ 5 Present address: California Institute of Environmental Studies, 3408 Whaler Ave., Davis, CA 95616 \\ 6Present address: 45 Parkside Dr., Davis, CA 95616
}

\begin{abstract}
We summarized historical knowledge from 1912 to 1998 of 13 known breeding colonies of Ashy StormPetrels (Oceanodroma homochroa) at Santa Cruz Island, California. Breeding was first reported by naturalists at Painted Cave (1912), Scorpion Rocks (1928), and Orizaba Rock (1937). During early seabird colony surveys of the Channel Islands, breeding was also noted at Cavern Point Cove Caves (1970), Diablo Rocks (1976), and Gull Island (1977). During 1991-1998, more extensive surveys of nearly all sea caves and offshore rocks documented additional breeding at Bat Cave, Cave of the Birds' Eggs, Del Mar Cove Cave, Del Mar Rock, Dry Sandy Beach Cave, Shipwreck Cave, and Willows Anchorage Rocks. Historical impacts apparently occurred from specimen collecting and interference by other nesting seabirds; however, guano harvesting may have had major impacts on nesting habitats at Scorpion Rocks (main rock) and Orizaba Rock. Impacts from organochlorine pollutants were likely extensive, and population sizes at all colonies may have been lower in the 1960s and 1970s when organochlorine pollution was at its highest level. Standardized monthly nest monitoring during 1995-1998 was used to measure reproductive success and population size at 5 colonies, creating a baseline for long-term trend monitoring that has continued annually to 2016. Mist net captures were used to estimate population sizes at 2 colonies in 1991. Estimated population size for Santa Cruz Island in 1991-1998 was 338 pairs, greater than previously reported for 1976-1977 (45-55 pairs), but the more recent estimate includes more colonies (especially 3 large colonies in sea caves), different methods of estimation, and likely some recovery from impacts associated with organochlorine pollution.
\end{abstract}

REsumen.-Resumimos el conocimiento histórico comprendido entre los años 1912-1998 de 13 colonias conocidas de reproducción del Paíño Cenizo (Oceanodroma homochroa) en la isla de Santa Cruz, California. Los naturalistas reportaron eventos reproductivos de esta especie por primera vez en Painted Cave (1912), Scorpion Rocks (1928) y Orizaba Rock (1937). Durante los primeros estudios de las colonias de aves marinas en las Islas del Canal (Channel Islands), también se registraron eventos reproductivos en Cavern Point Cove Caves (1970), Diablo Rocks (1976) y la Isla Gull (1977). Durante los años 1991-1998, estudios más extensos de casi todas las cuevas marinas y costas rocas, documentaron eventos reproductivos adicionales en Bat Cave, Cave of the Birds' Eggs, Del Mar Cove Cave, Del Mar Rock, Dry Sandy Beach Cave, Shipwreck Cave y Willows Anchorage Rocks. Los impactos históricos aparentemente ocurrieron a partir de la colecta de especímenes y de la interferencia de otras aves marinas nidificantes. Sin embargo, la recolección de guano pudo haber tenido el mayor impacto en los hábitats de anidación en Scorpion Rocks (peñasco principal) y en Orizaba Rock. El impacto de los contaminantes organoclorados seguramente fue importante y el tamaño de la población en todas las colonias probablemente disminuyó entre los años 1960 y 1970, cuando la contaminación por compuestos organoclorados llegó a su máximo nivel. Durante los años 1995-1998, se llevó a cabo un monitoreo mensual sistematizado de nidos, con el propósito de medir el éxito reproductivo y el tamaño poblacional de cinco colonias, este monitoreo estableció la base para su seguimiento a largo plazo que continuó hasta el 2016. En 1991, capturas con redes de niebla se usaron para estimar los tamaños poblacionales de dos colonias particulares. Entre los años 1991-1998, el tamaño poblacional estimado en la Isla Santa Cruz fue de 338 pares, mayor que el reportado previamente entre los años 1976-1977 (45-55 parejas), pero estimaciones más recientes incluyen más colonias (especialmente, 3 grandes colonias en cuevas marinas), diferentes métodos de estimación y, probablemente, cierta recuperación de los impactos asociados a la contaminación por organoclorados.

*Corresponding author: bill_mciver@fws.gov

$\dagger$ Deceased 
The Ashy Storm-Petrel (Oceanodroma homochroa; ASSP) is a relatively rare seabird (family Hydrobatidae) with breeding restricted almost entirely to California, USA, but small numbers also nest in northwestern Baja California, Mexico (Ainley 1995, Carter et al. 2008a, 2016a). Four of the 5 largest concentrations of breeding ASSP in the world occur in the Channel Islands: 1 at Prince Island (off San Miguel Island), 1 at Santa Barbara Island (including Sutil Island), and 2 at northwest and northeast Santa Cruz Island (SCZ). ASSP studies at SCZ have become the cornerstone for tracking the health of this species in the Channel Islands. A nest monitoring program at SCZ since 1995 has provided knowledge of population trends, reproductive success, timing of breeding, and predation and other threats in the Channel Islands, most notably effects from organochlorine pollutants (DDT and PCB) (McIver 2002, Carter et al. 2008b, McIver et al. 2009, 2018). Since 2008, restoration has been conducted at Orizaba Rock, where numbers of ASSP nests had declined significantly from 1997 to 2005 coincident with the presence of bright lights from squid fishing boats (McIver et al. 2016, unpublished data).

Available information about ASSP colonies prior to 1995-1998 is mainly unpublished and not readily available. We collated and summarized unpublished and published information on breeding population sizes, distribution, and potential trends for ASSP at all 13 known SCZ colonies during the 1912-1998 period. Knowledge of breeding during 1912-1955 was obtained almost entirely from egg and bird specimens collected by naturalists, whereas data during the 1960s to the 1990s were gathered for various purposes by a number of research institutions. Data during 1991-1998 were obtained almost entirely by the authors and many assistants working for Humboldt State University (HSU). Access to historical information will assist researchers and resource managers in the development and interpretation of future surveys, monitoring, trend assessments, and restoration actions for the ASSP at SCZ.

To introduce the types of data summarized and some of the key individuals and organizations that obtained data throughout the 86-year period from 1912 to 1998, we provide a brief chronological sketch of the discovery of these ASSP colonies and the work conducted during
1991-1998. Several naturalists described bird life at SCZ in the late 19th and early 20th centuries (Streator 1886, Blake 1887, Townsend 1890, Beck 1899, Mailliard 1899, Linton 1908, Willett 1910, Howell and van Rossem 1911, Wright and Snyder 1913, Dawson 1915, Howell 1917), but they did not focus on documenting colonies of nesting seabirds. This was probably because of (1) much early focus on potential island-endemic land birds; (2) SCZ's lack of large offshore rocks (such as Prince Island off San Miguel Island) with many breeding seabirds; (3) difficult access to offshore rocks, caves, and cliffs along the steep and exposed northern coastline where most ASSP and other seabirds were found breeding during 1991-1998 (Carter et al. 1992, unpublished data); and (4) mammalian predators (i.e., island fox [Urocyon littoralis] and island spotted skunk [Spilogale gracilis amphiala]) preventing seabirds from breeding in most coastal areas on the main island (Howell 1917, Hunt et al. 1979, McIver et al. 2016).

Naturalists H. Wright and G.K. Snyder first discovered nesting ASSP on SCZ at Painted Cave in 1912 (Wright and Snyder 1913; Fig. 1A). This was the first well-documented report of ASSP nesting in the Channel Islands, although nesting had been noted in 1875 at San Miguel Island (likely Prince Island) (Henshaw 1876; see Carter et al. 2016b). Nesting was next documented on SCZ in 1928 at Scorpion Rocks by naturalists L. Peyton, S. Peyton, M. Badger, and J.E. Paquette, and then at Orizaba Rock in 1937 by Badger and Paquette. Between 1928 and 1955, Scorpion Rocks and Orizaba Rock were the only 2 locations in the Channel Islands where ASSP breeding was documented and specimens were obtained (Hunt et al. 1979).

In 1967-1977 funding by federal agencies was first provided to major research organizations to document and study seabird breeding colonies in the Channel Islands. The Smithsonian Institution's Pacific Ocean Biological Survey Program (POBSP) documented suspected breeding at Scorpion Rocks and Orizaba Rock in 1967 (DeLong 1967), and specimens apparently were collected at Cavern Point Cove Caves in 1970 (Carter unpublished notes). In 1976-1977 the University of California Irvine (UCI) documented breeding at Scorpion Rocks, Orizaba Rock, Diablo Rocks, and Gull Island; overall, a small population 


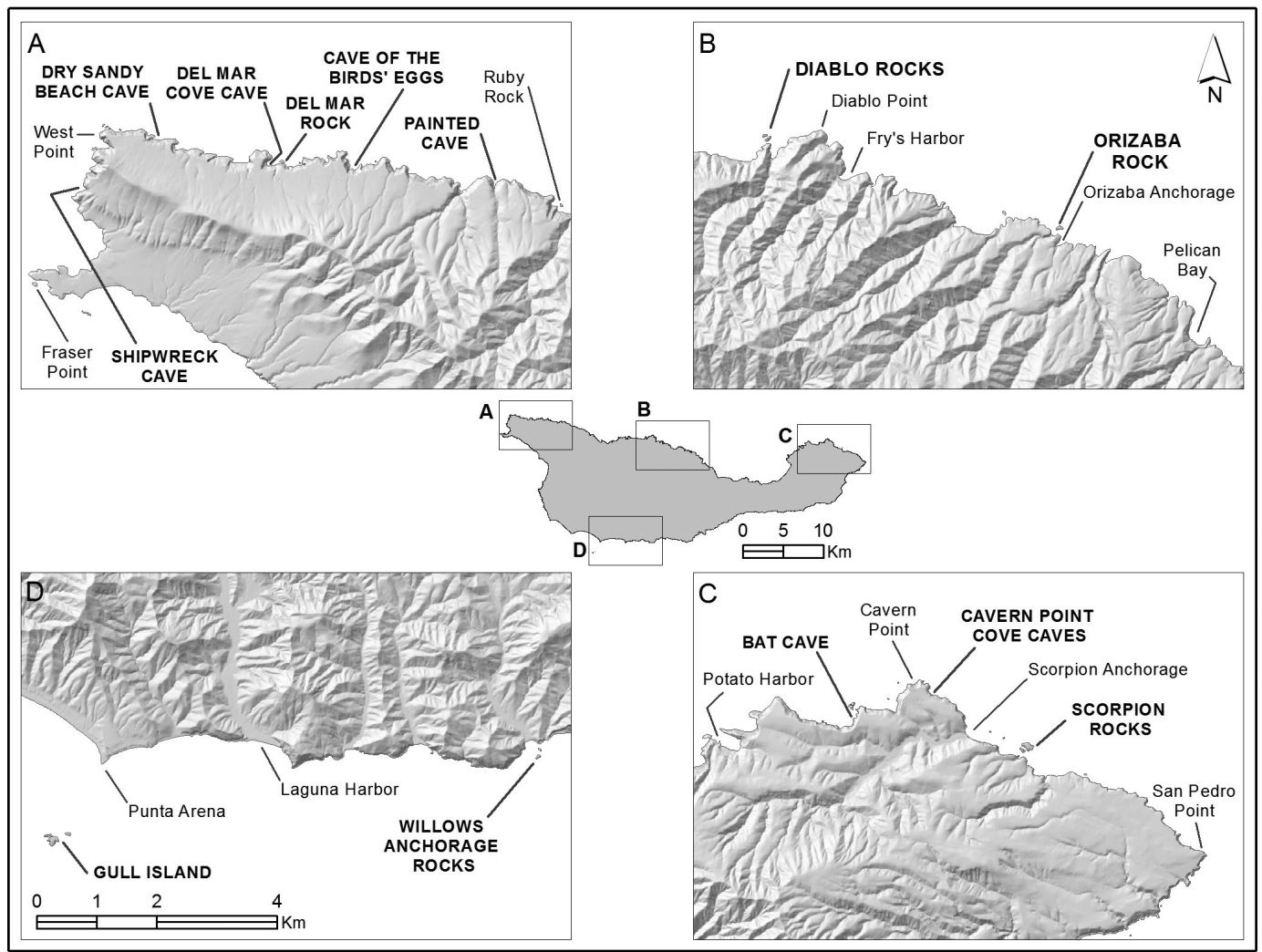

Fig 1. Locations of Ashy Storm-Petrel colonies (bold capitals) at Santa Cruz Island, California: A, northwest section; B, north-central section; $\mathbf{C}$, northeast section; $\mathbf{D}$, south section.

of about 50 pairs of ASSP was estimated for SCZ (Hunt et al. 1979, Sowls et al. 1980). During 1975-1977, relatively large colonies of ASSP were also well documented at Prince Island and Santa Barbara Island (including Sutil Island) (Hunt et al. 1979, 1980).

In 1991 HSU resurveyed seabird colonies in the Channel Islands. Despite most effort being focused on ASSP at Prince Island and Santa Barbara Island (including Sutil Island), 3 colonies were discovered at SCZ at Cave of the Birds' Eggs, Del Mar Rock, and Willows Anchorage Rocks (Carter et al. 1992). In 1992 the Western Foundation of Vertebrate Zoology (WFVZ) and the U.S. Fish and Wildlife Service (USFWS) collected ASSP eggs from Orizaba Rock and Cave of the Birds' Eggs for organochlorine pollutant (DDT and PCB) analyses (Fry 1994, Kiff 1994, Carter et al. 2008b). During this work, one ASSP nest was found at Del Mar Cove Cave. During 1994-1997 HSU conducted additional surveys of ASSP and Scripps's Murrelet (Synthliboramphus scrippsi; SCMU) throughout the Channel Islands, focusing on areas and habitats not well surveyed in 1991 (H.R. Carter unpublished data; see Whitworth et al. 2014, Carter et al. 2016b, Whitworth and Carter 2018). In 1994 we discovered ASSP nesting in Bat Cave and Dry Sandy Beach Cave, but nesting in Shipwreck Cave was not discovered until 1997 when searches were first conducted there. In 1995-1998 to examine population size, reproductive success, timing of breeding, and predation, HSU initiated a long-term nest monitoring program at 5 colonies: Bat Cave, Cave of the Birds' Eggs, Cavern Point Cove Caves, Dry Sandy Beach Cave, and Orizaba Rock (McIver 2002, McIver et al. 2009, 2016, 2018). Monitoring has continued with support from other entities (e.g., Montrose Settlements Restoration Program). Mist net capture rates were also examined at Scorpion Rocks, Orizaba Rock, Willows Anchorage Rocks, and 
Diablo Rocks in 1991 and 1994-1997 (Carter unpublished data).

\section{Methods}

Nest Searches, Nest Monitoring, and Population Sizes (1991-1998)

In 1991 and 1994 we conducted ASSP nest searches by inspecting potential nest crevices with small handheld flashlights at SCZ colonies at coastal locations that were accessible with an inflatable boat. In 1991 searches were focused mainly at known colonies, but in 1994 we examined most accessible coastal areas, especially numerous sea caves (Bunnell 1988) largely omitted in 1991 and during earlier surveys. We recorded crevices and suitable breeding sites with evidence of breeding (i.e., eggs, chicks, or adults) in the survey year as "active nests" or as "old nests" if sites contained evidence of prior breeding. In 1991 we conducted a count of suitable nest crevices in October after the breeding season at Gull Island, Willows Anchorage Rocks, and Scorpion Rocks (see Carter et al. 1992 for details of survey methods). In 1995-1998 we monitored 5 colonies (Bat Cave, Cave of the Birds' Eggs, Cavern Point Cove Caves, Dry Sandy Beach Cave, and Orizaba Rock) every 3-4 weeks between May and November. Details about monitoring methods were provided in McIver (2002) and McIver et al. (2009, 2016). Each monitoring trip generally included an examination with small flashlights of all accessible habitats in order to search for and assess ASSP activity at nests, as well as to mark and map nests. To minimize disturbance, we did not handle or band adults in nests (McIver 2002). During 1991-1998, we determined breeding population size in a specific year ("population size") at most locations by tallying all nest sites with evidence of egg laying in the survey year. In 1991, however, estimates for Gull Island, Willows Anchorage Rocks, and Scorpion Rocks were derived from counts of potential nest sites adjusted with a rough correction factor for occupancy (Carter et al. 1992).

\section{Historical ASSP Information (1912-1992)}

In order to summarize historical information collected before 1993, we conducted a literature search starting with unpublished summaries of ASSP at SCZ after surveys in
1967-1970 by the Smithsonian Institution's Pacific Ocean Biological Survey Program (DeLong 1967), 1975-1977 by the University of California Irvine (Hunt et al. 1979), and 1991 by HSU (Carter et al. 1992). We also augmented this information with unpublished field notes from surveys in 1975-1977 (archived at the Bureau of Ocean Energy Management, Camarillo, CA), personal field notes from surveys in 1976-1977 provided to H.R. Carter by Steven M. Speich (1945-2001), and field notes from the 1991 survey (archived at the USFWS, San Francisco Bay National Wildlife Refuge, Fremont, CA). Next we examined data from museum specimens identified through in-person museum visits or VertNet (with follow-up emails with museum staff); especially important were data and correspondence with the WFVZ; Biodiversity Institute and Natural History Museum, University of Kansas; California Academy of Sciences; Field Museum of Natural History; James R. Slater Museum of Natural History; Natural History Museum of Los Angeles County; Museum of Comparative Zoology, Harvard University; Museum of Natural History, University of Arizona; Santa Barbara Museum of Natural History; and San Diego Museum of Natural History. We also examined unpublished collectors' field notes housed at the WFVZ for Martin C. Badger (1892-1971), Dudley S. DeGroot (1899-1970), Donald R. Dickey (1887-1932), Ed N. Harrison (1914-2002), John R. Pemberton (18841968), Lawrence G. Peyton (1890-1985), and Lawrence T. Stevens (1903-1967). We obtained an unpublished manuscript about Howard W. Wright (1892-1977) from the Santa Cruz Island Foundation and historical information about guano harvesting from Islapedia.com. We also evaluated unpublished notes related to egg collecting for organochlorine studies in 1992 (W.T. Everett and S. Sumida unpublished notes) and 1996-1997 (H.R. Carter and W.R. McIver unpublished notes).

\section{RESUlTs}

\section{Colony Summaries}

Bat Cave $\left(34.051645^{\circ} \mathrm{N}, 119.572417^{\circ} \mathrm{W}\right)$.On 14 July 1994, 28 nests were noted during a brief search. On 10 August 1994, 64 nests were noted during a thorough search. Three ASSP carcasses were noted on each trip, indicating some predation. In 1995-1997 this 
colony was monitored through monthly nest searches and nest checks; totals of 66, 97, and 71 nests were documented each year, respectively (McIver 2002, McIver et al. 2009; Table 1). In 1996-1997, eggs were collected for studies of organochlorine pollution and eggshell thinning (Carter et al. 2008b). In 1996, 8 and 2 "viable" (i.e., incubated) eggs were obtained on 5 June and 25 June, respectively, from a specific portion of the cave not included in breeding success analyses. In 1997 as many as 8-9 viable eggs were collected on 22 July $(n=3), 19$ August $(n=3)$, and 21 August ( $n=2-3$ eggs). One "salvaged" egg (i.e., whole or broken but unattended egg) was found on 19 August 1997 and 2-3 salvaged eggs were found on 21 August 1997. Reduced nesting was not noted in 1997 in the portion of the cave where 1996 collecting was conducted (Carter and McIver unpublished data). Extensive predation by Barn Owls (Tyto alba; BNOW) was noted in 1995-1997, involving 11-39 carcasses per year (McIver et al. 2018).

Cave of the Birds' Eggs $\left(34.072818^{\circ} \mathrm{N}\right.$, $\left.119.875079^{\circ} \mathrm{W}\right)$.- On 6 May 1991, 3 old eggshell fragments were found, but it was not possible to conduct a survey later that breeding season (Carter et al. 1992). In 1992, eggs were collected for studies of organochlorine pollution and eggshell thinning (Fry 1994, Kiff 1994). On 4 June 1992, no eggs were found, but 1 adult was captured (Everett unpublished field notes). On 25 June 1992, 2 viable eggs (i.e., eggs incubated by an adult) were collected and 1 chick about 1 week old was noted (Everett unpublished field notes). On 13 July 1992, 2 viable eggs and 1 salvaged egg were collected. On 18 August 1992, 2 eggs were salvaged. In total for 1992, 4 viable eggs and 3 salvaged eggs were collected (Everett unpublished field notes). McIver et al. (2016: Appendix 2) reported that

on 4 and 25 June 1992, 3 viable eggs were collected. ... However, 12 egg specimens collected ... in 1992 (presumably including viable eggs and eggshell fragments) are housed in the WFVZ, including 12 May $(n=$ $1), 4$ June $(n=1), 25$ June $(n=2)$, 13 July $(n$ $=6)$, and 18 August $(n=2)$.

In 1994, only 3 nests were found on 7 May, but 8 nests were found on 10 July and 9 August; in addition, 1 carcass was found on 7 May and 2 feather piles were found on
10 July, indicating some predation (McIver et al. 2018).

From 1995 to 1998, this colony was monitored through monthly nest searches and nest checks; $13,11,9$, and 9 nests were documented each year, respectively (McIver 2002, McIver et al. 2009, 2016; Table 1). Fewer nests in 1997-1998 than in 1995-1996 signaled a drop in subsequent numbers at this colony through 2000 (based on late-summer nest counts; see McIver et al. 2016), coincident with light from active squid fishing activities in the area (McIver et al. 2016). Impacts from the 1998 El Niño event on population size were not evident (McIver 2002, McIver et al. 2009). In 1995-1997 only 1 ASSP carcass was found, indicating low predation (McIver et al. 2018).

Cavern Point Cove Caves (34.054116 ${ }^{\circ}$, $\left.119.561784^{\circ} \mathrm{W}\right)$.- On 13 July 1970 , L.N. Huber collected 8 adults and 2 nestlings (Carter unpublished notes) in a "cave on the NE coast of island; about 20 pairs nesting in cavemostly on well-incubated eggs." Based on the general location described, the small number of nesting pairs reported, and the easy access by small boat from Scorpion Harbor, this location coincides with what we know to be Cavern Point Cove Caves. Nesting was next described here in 1994 (Carter unpublished notes) when 6 nests were found during searches of caves \#5 and \#4 (in Bunnell 1988) on 14 July. On 4 August 1994, 7 nests were found in cave \#5. No carcasses were noted in 1994. In 1995-1997 this colony was monitored through monthly nest searches and nest checks; 16, 11, and 17 nests were documented each year, respectively, and no carcasses were found in any year (McIver 2002, McIver et al. 2009, 2018; Table 1). In 1997, 1 egg was collected for studies of organochlorine pollution and eggshell thinning (Carter et al. 2008b).

Del Mar Cove Cave $\left(34.073086^{\circ} \mathrm{N}\right.$, $\left.119.894743^{\circ} \mathrm{W}\right)$. - One nest with an adult incubating an egg was found in June 1992, but the egg was broken in transport and categorized as a salvaged egg (Everett unpublished field notes). In 1994 we were not aware that a nest had been found at this location in 1992 and therefore passed by this area on 9 August without checking for nests, assuming that suitable habitat was not available.

Del Mar Rock $\left(34.073705^{\circ} \mathrm{N}, 119.892018^{\circ}\right.$ W).-_On 13 May 1991, 1 nest was found on this steep small rock; it was not possible to 


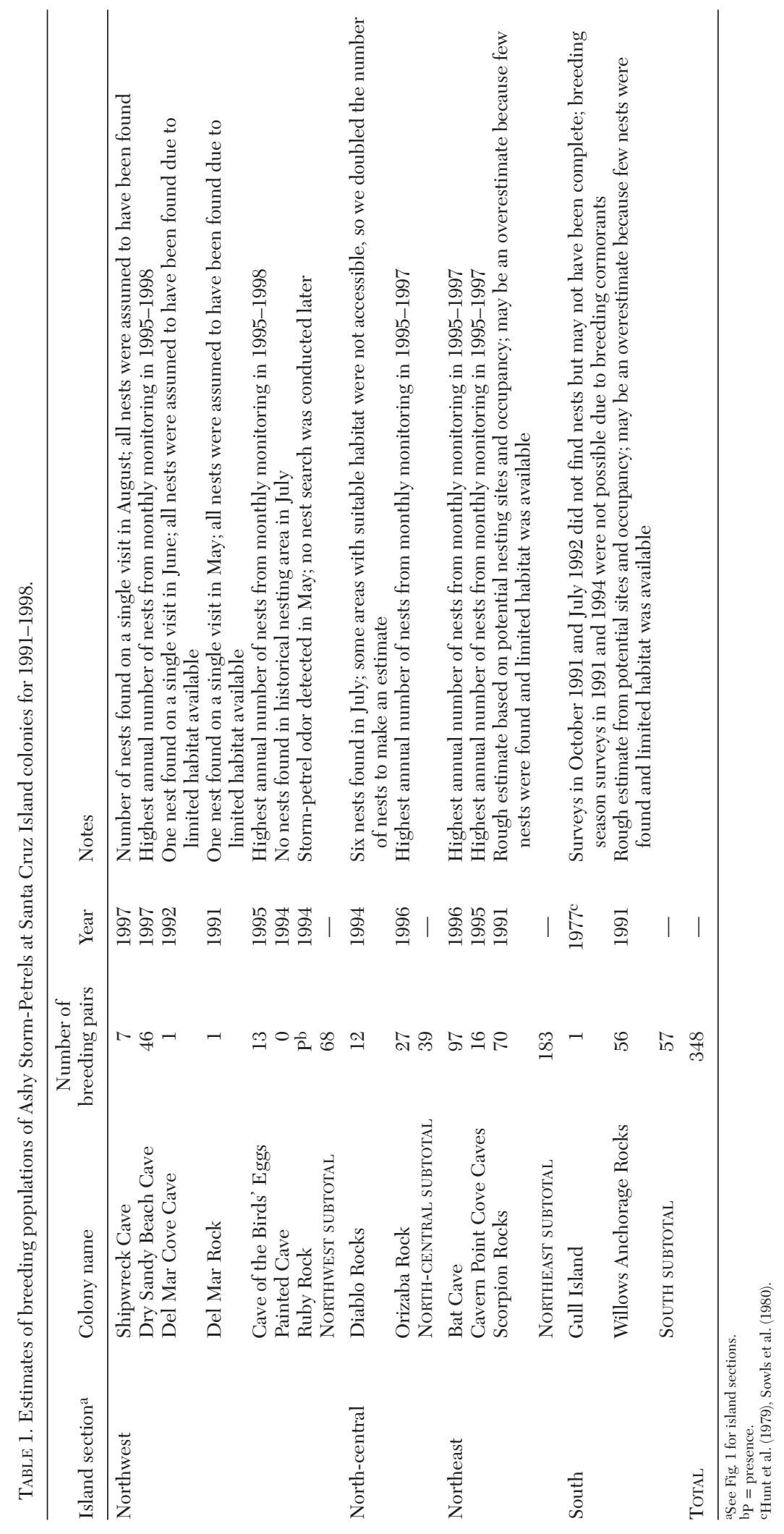


conduct a survey later that breeding season (Carter et al. 1992, Carter unpublished notes). Consequently, 1 nest was estimated in 1991 (Carter et al. 1992). On 9 August 1994, no nests were found; the original crevice site could not be relocated and no other potential sites were noted.

Diablo Rocks $\left(34.058081^{\circ} \mathrm{N}, 119.766694^{\circ}\right.$ W).- On 15 July 1976, 4 nests were found on the larger rock (Hunt et al. 1979). Nests contained an adult incubating an egg $(n=1)$, an adult in a crevice $(n=1)$, a chick $(n=1)$, and storm-petrel odor $(n=1)$ (S.M. Speich unpublished field notes). Ten breeding pairs were estimated for 1976 (Hunt et al. 1979, Sowls et al. 1980). In 1991 this ASSP colony was surveyed on 5 May; 12 potential nest sites were noted, but none contained adults (Carter et al. 1992). On 8 May 1994, 1 nest was found on the larger rock. On 14 July 1994 both rocks were searched and a total of 6 nests were found, 3 on each rock. A total of 54 birds were captured using mist nets on 10-11 July 1994, and 12 pairs were estimated for 1994 (Carter unpublished data; Table 1).

Dry Sandy Beach CaVe $\left(34.076701^{\circ} \mathrm{N}\right.$, $\left.119.912303^{\circ} \mathrm{W}\right)$.- On 10 July 1994,15 nests were noted; a month later on 9 August 1994, 11 additional nests were found. No carcasses were noted in 1994. During 1995-1998 this colony was monitored through monthly nest searches and nest checks; totals of $26,41,46$, and 42 nests were documented each year, respectively, and only 1 carcass was found in 1996 (McIver 2002, McIver et al. 2009, 2018; Table 1). Impacts on nest occupancy from the 1998 El Niño event were not evident (McIver 2002).

GULL ISLAND $\left(33.95039^{\circ} \mathrm{N}, 119.825402^{\circ}\right.$ W).-On 12 April 1977, 1 nest was found but no details were recorded (Hunt et al. 1979). One pair was estimated for 1977 (Hunt et al. 1979, Sowls et al. 1980). No nests were found during a nest search on 24 October 1991 (Carter et al. 1992; Table 1). We could not conduct a nest search earlier that breeding season and during 1994-1996 due to concern about disturbing breeding Brandt's Cormorants (Phalacrocorax penicillatus; BRAC) (Carter et al. 1992). No nests were found during a search on 13 July 1992 , but it is not clear what areas were searched (Everett unpublished field notes).

Orizaba Rock $\left(34.046862^{\circ} \mathrm{N}, 119.722974^{\circ}\right.$ W).--On 23 May 1937, 10-16 eggs were collected on a detached rock at Orizaba Harbor by M.C. Badger, L.T. Stevens, and J.E. Paquette (1908-1988). Five eggs collected by Badger and Paquette were labeled as "Orizaba Harbor." Museum records for Badger and Paquette suggested, however, that at least 11 eggs were actually collected at Orizaba Rock by these 2 collectors. Stevens labeled at least 5 eggs as being collected from "Santa Cruz Island," but his field notes clearly indicated that these eggs were collected at Orizaba Harbor. On 22 May 1938, Badger and Stevens collected at least 14 more eggs. In addition to 13 available egg specimens, Stevens described another specimen collected at "Santa Cruz Island" (likely Orizaba Rock, based on set mark "446$1 / 1$ " shortly before set mark " $450-2 / 1$," which is labeled as Orizaba Rock) that was not preserved: "Nest in little crevis [sic] in rock egg placed on sand. Egg chipped while rolling from nest. Bird on nest. Destroyed." Five eggs listed as collected by E.N. Harrison were likely collected by Badger or Stevens and obtained later by Harrison. Hunt et al. (1979) treated egg specimens from 1937-1938 labeled as being collected from Orizaba Rock as being from Painted Cave, apparently because the collectors were not familiar with the name Orizaba Anchorage given that they referred to Orizaba Rock as "Sppit Rock" (see below). Badger (unpublished field notes) clearly confirmed that both Scorpion Rocks and Orizaba Rock were visited on the same days in 1937 and again in 1938-quite feasible because these rocks are only $16 \mathrm{~km}$ apart.

On 7 or 8 September 1967, storm-petrel odor was detected at Orizaba Rock (DeLong 1967 ) and the presence of a colony was suspected. On 15 July 1976, 8 nests "were found in the 'Catacombs' under the highest part of the rock. Two or three times this number could have existed there. In 1977, eight nests were found" (Hunt et al. 1979:33). Nests in 1976 contained an adult incubating an egg $(n=2)$, an egg only $(n=1)$, a chick $(n=2)$, and an adult $(n=3)$ (Speich unpublished field notes). Hunt et al. (1979) coined the name "Sppit Rock" for Orizaba Rock, named after S.M. Speich and R.L. Pitman who thought they had first discovered this ASSP colony (Speich personal communication). On 17 February 1977 field workers also noted that crevices

smelled of petrels. One outcropping of rock on the NW end was cleared of shells = an obvious OCB $[\mathrm{BNOW}$ roost and probably 
breeding area. The shells cleared were collected and brought back onto the boat. ... After anchoring, birds were seen outside the lights of the boat. We turned the spotlight on and were able to attract and/or blind the Ashy Petrels into the boat. Of these PTAs [ASSP] some had brood patches. It was a very foggy night and the lights on the back of the boat may have attracted them.

[Hunt et al. 1979, unpublished trip notes]

Twenty breeding pairs were estimated for 1976-1977 (Hunt et al. 1979, Sowls et al. 1980).

On 5 May 1991 this colony was surveyed, but no nests were found (Carter et al. 1992, unpublished notes). In 1992 this colony was selected for studies of organochlorine pollution and eggshell thinning (Fry 1994, Kiff 1994, Carter et al. 2008b, McIver et al. 2016). On 13 July 1992, 8 viable eggs and 1 salvaged egg were collected; 1 chick about 2-3 weeks old was also noted (Everett unpublished field notes). On 18 August 1992, 1 egg was salvaged (but did not become a specimen) and 3 downy chicks were noted (Everett unpublished field notes). In total for 1992, 8 viable eggs and 2 salvaged eggs were collected. McIver et al. (2016: Appendix 2) reported that "on 13 July 1992, 11 viable eggs were collected." However, with access to more information, we found that the revised details provided herein are correct. On 10-11 July 1994, 13 nests were found and 68 birds were captured using mist nets (Carter unpublished notes). On 9-10 August 1994, 7 nests were found, 24 birds were captured in mist nets, and no carcasses were noted.

During 1995-1997 this colony was monitored through monthly nest searches and nest checks and periodic mist net captures; totals of 20,27, and 8 nests were documented in 1995, 1996, and 1997, respectively, and 2 carcasses were found each year (McIver 2002, McIver et al. 2009, 2018; Table 1). In 1995 mist nets were set up on a total of 5 nights in June and July, resulting in captures of 27-45 birds per night (Carter et al. unpublished notes). In August ( $n=2$ nights) captures decreased to 16-18 birds per night. Only 1 bird was captured in September $(n=1$ night $)$ and no birds were captured in October $(n=1$ night). In 1996, 14-18 birds were captured in late July ( $n=1$ night) and early August ( $n=1$ night) and no birds were captured in late August $(n=1$ night) and mid-September ( $n=1$ night) (Carter et al. unpublished notes).

Painted Cave $\left(34.070577^{\circ} \mathrm{N}, 119.860389^{\circ}\right.$ W).-On 10 July 1912, nesting ASSPs were found by H.W. Wright and G.K. Snyder (1889-1915). Wright and Snyder (1913:88) described this event in detail.

We set sail about noon [on 6 July 1912] for Santa Cruz Island; and the next few days were spent in loafing about the beautiful little harbors that this island affords. Various trips into the canyons netted little of unusual interest, though the numerous resident land birds were much in evidence. It was not until the far end of the island was reached that the "prize find" of the trip was made. We had stopped to explore the "Painted Cave" from a scenic point of view, but once there the great number of Pigeon Guillemots [Cepphus columba; PIGU] present invited search for their nests. One large sloping ledge, which seemed particularly good, was being explored by the aid of a lantern with the hope of finding a guillemot's egg unhatched. The way was dark and as the lantern was flashed about to find secure footing it fell on a small bird crouched on the open floor of the ledge. The bird, evidently blinded by the light, was easily captured and proved to be an Ashy Petrel brooding a well incubated egg. Thus encouraged, a most careful search was made with the result that four eggs and one small young, together with the adults, were taken. The "nests" were all entirely exposed, though one was in a shallow hole in the rocky side of the cave. This in light of their usual breeding habits seems strange, because numerous fragments of rock which had fallen on the ledge afforded hiding places, and were utilized for this purpose by the Guillemots. A single addled Guillemot's egg was an incident of the search, while the young in all stages were quite numerous. We went from the Painted Cave, on Santa Cruz, to Santa Rosa where we anchored over night.

Wright also recalled this trip to his son, H. Wright Jr. (Wright et al. [no date] unpublished manuscript):

So we spent a night there [anchored behind Ruby Rock], and the next day went up to Painted Cave, in the dory, where Smith and I found some petrels nesting in a cave, there which no one knew about. So we got some eggs and some birds. [H. Wright Jr.: There are no petrels around now are there?] Darn few now. There were rare petrels, not the black ones, but Least Petrels [actually Ashy 
Storm-Petrels]. It tells about them in this bird book I have, tells about our finding them in the Painted Cave. There were about six of them we found in that first cavern, way up on the cliff there, and lots of those guillemots, nesting again. [H. Wright Jr.: You know there wasn't a sign of any birds nesting when we were there.] These things are quiet as hell, up there on a ledge, back behind the rock. You climb up and find that little bird sitting on her nest, and you kill the bird and take the eggs, proud of yourself. So we went back to Valdez.

Four adults and 2 eggs from the 1912 trip are preserved as museum specimens at the California Academy of Sciences, San Francisco, CA; Museum of Comparative Zoology, Harvard University, Cambridge, MA; and the WFVZ, Camarillo, CA (Carter unpublished notes). On 23 June 1913, D.S. DeGroot collected an egg from an incubating adult at the same location and noted that it was the "only bird of the species nesting here at this time, so far as we could find" (Hunt et al. 1979). In DeGroot's field notes, he stated that this egg was found by H. Moran and then collected by DeGroot. On 3 August 1913, Wright (1913) revisited Painted Cave and "made a thorough search for the 'nests' of the Ashy Petrel. ... I could find nothing but a few egg shells, which would indicate that the birds either bred earlier, or else did not breed there at all this season." On 17 July 1914, an egg and an adult were also collected by Wright.

On 25 June 1976, 2 hours (13:30-15:40) were spent exploring Painted Cave, but no sign of ASSP nesting was found. Hunt et al. (1979:33) noted further that "it is a little unclear, however, exactly where nesting birds were found here previously (e.g., Bent 1919 refers to 'the painted caves' of Santa Cruz Is. suggesting more than one location)." However, Bent (1919:167-168) clearly described collecting Pigeon Guillemots in only one location with the unique characteristics of Painted Cave. On 6 May 1991, no evidence of nesting was found in the back end or lower sides of the cave, although upper cave habitats were not checked (Carter et al. 1992, Carter unpublished notes). On 25 June 1992, no nests were found, but records do not indicate which cave areas were checked (Everett unpublished field notes). On 7 May 1994, no potential habitat was found in the back end and most of the smooth-walled inside of the cave. Two side caves, however, about $20 \mathrm{~m}$ high and $30 \mathrm{~m}$ from the cave entrance were noted (requiring more time and extensive climbing skill on a future trip) that closely matched the description of the 1912 location (Wright and Snyder 1913; see above). Outside the cave entrance no ASSP nests were found, but storm-petrel odor and potential crevices were present. Two Cassin's Auklet (Ptychoramphus aleuticus; CAAU) nests were found outside the cave entrance on steep slopes in vertical cracks. On 14 July 1994 the 2 side caves within Painted Cave were carefully searched, but no ASSP nests were found; a nest search outside the cave entrance could not be conducted on this trip.

Ruby Rock $\left(34.068357^{\circ} \mathrm{N}, 119.850349^{\circ}\right.$ W).-On 7 May 1994, storm-petrel odor was detected in several crevices, but no ASSPs were observed (Carter et al. 1992, Carter unpublished notes).

SCORPION ROCKS $\left(34.047325^{\circ} \mathrm{N}, 119.547536^{\circ}\right.$ W).-On 20 May 1928, 2 eggs and 1 adult were collected by L.G. Peyton, S. Peyton, M.C. Badger, and J.E. Paquette, followed by 4 eggs on 2 June 1928 by Peyton, D.S. DeGroot, and J.R. Pemberton. On 19 May 1929, 2 eggs and 1 adult were also collected by Peyton and Paquette. Hunt et al. (1979) reported that only 2 eggs were collected in June 1928 and none in 1929, likely because fewer egg records were accessible during the late 1970s. On 17 May 1936, Badger and L.T. Stevens collected 9 eggs at Scorpion Harbor. Apparently 4 of Badger's eggs and 1 adult were obtained later by E.N. Harrison. Badger (unpublished field notes) stated that he "went to Anacapa with Laurie [Stevens] then Scorpion Harbor"; Harrison did not appear to be on this trip. Badger, Stevens, and Paquette visited Scorpion Harbor on 23 May 1937 and collected at least 15 eggs. Stevens labeled 3 of 6 eggs as being collected from "Santa Cruz Island," but his field notes and set marks indicated that these eggs were collected at Scorpion Harbor. On 22 May 1938, Badger and Stevens visited Scorpion Rocks where Badger collected 3 eggs. On 26 May 1940, 1 egg was collected by S.A. Andresen. On 25 May 1941, Stevens and Edward M. Hall collected 3 eggs. On 22 May 1955, Stevens collected 1 egg specimen. In May 1936 and 1937, greater numbers were collected (9 and 15 eggs, respectively), but in May 1938, 1940, 1941, and 1955, only 3, 1, 3, 
and 1 eggs were collected, respectively, based on available museum specimens. Hunt et al. (1979) reported 10, 16, 19, 8, 3, and 3 eggs collected at Scorpion Rocks and "Orizaba Harbor (Painted Cave)" combined in 1936, 1937, 1938, 1940, 1941, and 1949, respectively.

On 7 or 8 September 1967, storm-petrel odor was detected at Scorpion Rocks (DeLong 1967). On 22 June 1976, an adult incubating an egg was found "under a large overhanging ledge on the south side of the largest rock. This was the only nest found during a $90 \mathrm{~min}$. daylight search" (Hunt et al. 1979). Steven M. Speich (unpublished field notes) provided a map showing the location of this nest on the inside of the rock about midway along the rock; it was described as "in a small cave like area-In crack in rock. Could be seen sitting on an egg. Nest near the back of area and up off the floor of the cave. Cave about 25 feet [7.6 m] below the island top. Hard to get at from bottom." On 25 June 1976, 9 ASSP were captured and banded over an unknown period of time using a mist net with broadcasted Leach's Storm-Petrel (Oceanodroma leucorhoa; LHSP) vocalizations; an adult was also pulled off an egg and banded (Hunt et al. 1979, Adams et al. 2016, Speich unpublished field notes). In 1977, 4 nests were found, but no details were provided (Hunt et al. 1979). We suspect that these nests were found on the smaller rock, as noted later in 1992 and 1994 (see below). Twenty breeding pairs were estimated for 1976-1977 (Hunt et al. 1979, Sowls et al. 1980).

In 1991 potential nesting habitat was scarce and no nests were found, but storm-petrel odor was noted at 1 crevice on the main rock on 2 May (Carter et al. 1992). Forty-two birds were captured in 2 mist nets on 3-4 May and 23 birds were captured on 20-21 May (Carter et al. unpublished notes). Mist net captures of 65 individuals (most with well-developed brood patches) indicated that a moderatesized breeding colony was present nearby. An estimated number of crevices as potential habitat was adjusted using $75 \%$ occupancy to derive a rough estimate of 140 breeding birds (70 pairs) in 1991 (Carter et al. 1992). In 1992 the main rock was searched on 26 June and 18 August for storm-petrel nests, but none were found. On the smaller rock, however, 1 adult was seen in a deep crevice on 26 June 1992 (Everett unpublished field notes). In 1994,
2 nests were found on the smaller rock on 5 May (but none on the main rock) and 37 birds were captured in a mist net on the main rock on 6-7 May; 88 birds were captured in flight with a dip net from our support vessel (F/V Instinct) in Scorpion Anchorage on 9-10 July. In 1997, 6 and 14 birds were captured in mist nets on 14-15 April and 15-16 May, respectively.

ShIPWRECK CAVE $\left(34.070363^{\circ} \mathrm{N}, 119.921372^{\circ}\right.$ W).--Large, breaking waves at the entrance prevented this cave from being checked during 1994-1996. Calm conditions with little swell allowed us a complete search on 19 August 1997 and we found a total of 7 nests (Carter unpublished data).

Willows Anchorage Rocks $\left(33.961212^{\circ} \mathrm{N}\right.$, $\left.119.752833^{\circ} \mathrm{W}\right)$.-On 7-8 May 1991, 6 crevices with adults only (i.e., no eggs were observed) were noted at night and 51 birds were captured in mist nets (Carter et al. 1992, Carter unpublished notes). We were not able to revisit this colony later during the main breeding season (Carter et al. 1992). On 23 October 1991, 3 nests and 10 sites with petrel odor were found and a total of 74 potential nesting sites were counted; this number, reduced by $75 \%$ estimated occupancy, yielded an estimated 111 breeding birds (55-56 pairs) in 1991 (Carter et al. 1992, Carter unpublished notes). On 8-9 May 1994, 2 nests were found and 32 birds were captured in mist nets.

\section{Discussion}

\section{Breeding Population Size and Distribution}

We estimated a breeding population of 348 ASSP pairs at SCZ for the 1991-1997 period by combining breeding pair estimates for 13 known colonies (Table 1). The 5 largest colonies (>20 breeding pairs each) were found at Bat Cave $(n=97)$, Scorpion Rocks $(n=70)$, Willows Anchorage Rocks $(n=56)$, Dry Sandy Beach Cave $(n=46)$, and Orizaba Rock $(n=27)$. Estimates for Bat Cave, Dry Sandy Beach Cave, and Orizaba Rock were relatively accurate based directly on the highest annual nest count obtained through monthly monitoring during 1995-1998. A similar number of nests was documented at Bat Cave in August $1994(n=62)$ as in $1995(n=$ 66), indicating that most nests can be detected during a single detailed survey after most or all egg laying has been completed and prior to fledging (McIver et al. 2016). However, 
estimates are based on nests that were easily accessible. An unknown number of additional nests were likely present in deeper crevices. For 5 small colonies not monitored monthly in 1995-1998, we used the maximum number of nests found during a single survey between 1976 and 1998 to estimate the number of breeding pairs: Gull Island $(n=1 ; 1977)$, Del Mar Rock $(n=1 ; 1991)$, Del Mar Cove Cave $(n=1 ; 1992)$, Painted Cave $(n=0 ; 1994)$, and Shipwreck Cave $(n=7$; 1997) (Table 1). Given asynchronous egg laying that likely occurred to some extent after many of these colonies were surveyed, the total number of nesting pairs was slightly underestimated. Habitat at these locations was limited, such that many more nests were not possible and most sites were likely occupied fairly early in the breeding season. Estimates for Diablo Rocks and Shipwreck Cave were less accurate. For Diablo Rocks we doubled the number of nests found in $1994(n=6)$ to account for inaccessible habitat, whereas Hunt et al. (1979) estimated 10 pairs for Diablo Rocks but found only 4 nests. At Shipwreck Cave habitat existed for greater numbers of nests, but the exposed nature of this cave allows high water intrusions and extensive spray that make some areas unsuitable for nesting in certain years; we could only evaluate nesting numbers in 1 year because of these conditions. At Ruby Rock we detected storm-petrel odor in 1994 but did not check for nests during the main breeding season. The limited amount of habitat at this rock, however, can only accommodate a few nesting pairs.

Estimates for Scorpion Rocks and Willows Anchorage Rocks were very rough, based on 1991 counts of potential nest sites with rough occupancy values applied (Carter et al. 1992). Counts of potential nest sites were incomplete at these locations because portions of these rocks were not accessible by foot; therefore, we could not fully assess the amount of suitable habitat. Substantial numbers of birds captured in mist nets at Scorpion Rocks and Willows Anchorage Rocks in 1991, however, suggest that relatively large numbers of birds breed there (Carter et al. 1992). Based on the number of mist net captures at Orizaba Rock and Diablo Rocks in 1994-1996, some birds attending colonies at SCZ were probably moving by Scorpion Rocks and Willows Anchorage Rocks at night and were attracted by the broadcasted vocalizations and headlamps used for mist netting. With limited habitat available at both locations and only 2-3 nests found at Scorpion Rocks in 1994 and at Willows Anchorage Rocks in 1991 and 1994, the numbers of birds nesting at these 2 colonies were most likely overestimated with the rough estimation techniques used in 1991.

Known breeding colonies occur in 4 areas of SCZ: (1) northeast SCZ (184 pairs at 3 colonies), (2) northwest SCZ (68 pairs at 5 colonies), (3) south SCZ (57 pairs at 2 colonies), and (4) north-central SCZ (39 pairs at 2 colonies). Sea caves mainly occur along the north coast (Bunnell 1988). They are formed by the action of high wave pressure from northwest swells, large waves, and storms mainly during winter on stronger igneous and metamorphic rock types that occur north of the major Santa Cruz Island fault (Dibblee 2001a, 2001b). Greater than $75 \%$ of the 114 sea caves that could be entered by flying ASSP, however, are inundated at high tide and have smooth cave walls without suitable nesting habitat (Bunnell 1988). Breeding ASSP were documented at only 5 caves (Bat Cave, Dry Sandy Beach Cave, Cave of the Birds' Eggs, Cavern Point Cove Caves, and Shipwreck Cave) with suitable dry-floor habitats for nesting that were not accessible to mammalian predators. Painted Cave was the only cave in which nests were found high on cave wall ledges. Small detached rocks also occurred mainly along the north coast, although ASSP nests were found only on Del Mar Rock, Diablo Rocks, Orizaba Rock, and Scorpion Rocks. Ruby Rock, Arch Rock, and Potato Rock also had potential nesting crevices, but nests were not found there in 1994, although Ruby Rock had storm-petrel odor on 7 May 1994. Small numbers of CAAU were found breeding on these rocks in 1994 (Ruby Rock: 1 nest with an adult on 7 May; Arch Rock: 5 burrows, probably CAAU, on 8 May; Potato Rock: 3 sites with eggshell fragments on 4 August), indicating that suitable habitat likely existed for ASSP on these rocks, but ASSP were possibly excluded by CAAU. The unnamed rock off Bat Cave also had sheer sides and was not accessible without technical climbing expertise and gear. More work is needed to assess possible breeding by ASSP at these latter 4 detached rocks. The south coast and the neck region of the north coast of SCZ are mostly composed of weaker sedimentary 
rock types (Dibblee 2001a, 2001b) which generally erode into moderate or gentle slopes. Few small caves occurred on the south coast of the island, and ASSP did not nest in any of them. Few detached rocks also occurred along the south coast, but Willows Anchorage Rocks and Gull Island did provide suitable crevices for nesting.

By 1997 we thought that almost all accessible nesting areas for ASSP along the coast of SCZ had been examined; only potential nesting habitats on the steep inaccessible cliffs on the northwest and northeast coasts remain to be examined. Hunt et al. (1979:33) also mentioned this problem: "If as the old Painted Cave records suggest, this species can effectively utilize cliff areas along the north side of the island, then a large amount of nesting habitat was not surveyed. We have no information as to how extensively this area was used by this species." Work conducted during 1991-1998 found substantial nesting in sea caves at the bases of cliff areas along the island's north side, but most cliff habitat was inaccessible. Two indications of suitable crevice nesting habitat in cliffs in this area are a nest found near a shallow entrance to Del Mar Cove Cave in 1992 and CAAU nests found in crevices on steep slopes outside of Painted Cave in 1994. Special climbing efforts are needed to search potential nesting areas in these cliffs, although the use of automated recording units (e.g., acoustic recorders), radar monitors, or mist nets at the tops or bottoms of these cliffs may help identify potential nesting areas with ASSP activity to focus future nest searches (e.g., Harvey et al. 2016).

\section{Historical Declines and Restoration}

Insufficient information is available to clearly measure changes in population sizes and habitats at most ASSP breeding colonies at SCZ for the 1912-1998 period. However, McIver et al. (2016) demonstrated declines at Orizaba Rock and Cave of the Birds' Eggs for the 1995-2004 period that apparently were related to bright lights from squid fishing boats. Carter et al. (2007) also mentioned possible declines at other ASSP colonies at SCZ. We hereafter summarize information about other factors that may have led to declines at SCZ colonies before 1995 and point out work that is still needed to investigate current status and potential restoration.
Specimen collecting.-Painted Cave has very limited nesting habitat, so it is no surprise that only 5 nests were noted on a high ledge there in 1912 (Wright and Snyder 1913). The collecting of eggs, chicks, and adults from this small colony in 1912-1914 may have caused the abandonment of breeding ASSP, partly explaining the lack of breeding records after 1914, although this location is also very difficult to access by climbing. In 1994 we were able to check the historic nesting location but found no nests; however, nesting status should be rechecked in future surveys (using qualified climbers, given the safety concerns). More work utilizing nest searches and acoustic recorders is needed to examine nearby nesting areas for possible shifts of nesting to outside of the cave entrance or to the back of the cave. Suitable habitat occurs nearby outside of the cave entrance where 2 CAAU nests were found in crevices in 1994.

At Scorpion Rocks the loss of very limited crevice nesting habitat on the main rock may have occurred when many eggs and birds were collected between 1928 and 1955 from the small cave under a boulder near the top of the steep inside of the main rock. On 2 June 1928, 7 eggs were first collected from this area. Subsequently, many eggs also appeared to have been taken from this same location, although in declining numbers over time: 8 eggs in 1937, 3 eggs in 1938, 1 egg in 1940, 3 eggs in 1941, and 1 egg in 1955. This area was reported as "rotten volcanic tuff" in 1928 (WFVZ 2888) and "loose rocks" in 1937 (WFVZ 96001-96004), suggesting a fragile crevice habitat that could have easily been damaged or removed during collecting activities at this difficult-to-access location. Only 1 nest was found in this area in 1976. No nests were found in 1991 and 1994, but nest searches occurred in early May before the main breeding season; however, available habitat in this area did not appear to be sufficient to support 7-8 nests, as found in 1928 and 1937. Artificial habitat could be used to restore apparent lost habitat (McIver et al. 2016, Parker 2016), which requires further assessment.

INTERFERENCE BY OTHER NESTING SEABIRDS.-During 1975-1977 Hunt et al. (1979) made frequent visits to Gull Island during the breeding season to monitor breeding seabirds. Only 1 ASSP nest was found with an estimated 75 CAAU nests in 1977, but the dates 
of nest searches were not given. In October 1991 no ASSP nests and only 3 CAAU nest sites with eggshell fragments were found during crevice counts (Carter et al. 1992, unpublished survey archive), but surveys were not conducted during the main breeding season in order to avoid impacting nesting BRAC. However, a substantial amount of suitable crevicenesting habitat was confirmed in 1991. In the 1970s the BRAC colony was relatively small, with 55 nests in 1976 and 67 nests in 1977 (Hunt et al. 1979); impacts to BRAC likely occurred during frequent on-island monitoring. Carter et al. (1992) reported 723 BRAC nests counted in aerial photographs from 15 June 1991. Some nesting habitat for ASSP and CAAU may have been affected by "interference" (i.e., nests, birds, and guano) from the larger BRAC colony which covered most of the tops of the 2 main Gull Island rocks by 1991. CAAU also may have outcompeted ASSP for crevice-nesting sites (Ainley et al. 1990). It is possible that we may have missed small numbers of ASSP nests during late October due to fledging or inconspicuous chicks and eggshell fragments. More work is needed to examine the status of ASSP and CAAU at Gull Island using acoustic recorders or other methods that do not disturb nesting BRAC.

Guano haRvesting.-Loss of burrow and crevice nesting habitats for seabirds during historic guano harvesting likely occurred at certain rocks off SCZ. This conservation issue for nesting seabirds at SCZ has not been previously recognized, so we discuss it in some detail because it has important implications for restoration actions. On 13 July 1902, guano harvesting at SCZ was first mentioned in the Los Angeles and Santa Barbara newspapers: "The launch Restless arrived yesterday [into Santa Barbara] from Santa Cruz Island with a cargo of guano" (fide Islapedia.com). The only rocks off SCZ where substantial guano deposits may have developed on relatively flat-topped rocks are Scorpion Rocks (main rock), Orizaba Rock, and Gull Island. The Restless was a small 42-foot (12.8-m) sloop that could carry only a few tons of guano. The 1902 cargo was most likely obtained at Scorpion Rocks (main rock; $\sim 0.5 \mathrm{ha}$ ) — which is the most accessible of these 3 rocks-near the long-established Scorpion Ranch (Gherini 2016). The size of the cargo was probably at least a few tons (see 1912 cargo below). On
10 August 1912, further guano harvesting at SCZ was reported in the Santa Barbara newspaper (fide Islapedia.com):

There are indications that the guano industry is to be revived on Santa Cruz Island after several years of inactivity. Five tons of the fertilizer was brought to Santa Barbara for local consumers on the El Pepito of San Pedro yesterday.

We suspect that guano had mainly been removed from Scorpion Rocks in 1902 and that a new source was discovered and harvested in 1912. Higher-elevation portions of Orizaba Rock $(\sim 0.2$ ha $)$ or Gull Island $(\sim 0.8$ ha $)$ could have been these new sources, but no other rocks exist at SCZ that are large enough or flat enough to provide tons of guano. Orizaba Rock is about $4-5 \mathrm{~km}$ west of Prisoner's Harbor, the main access for the central valley ranch since the 1850s (Gherini 2016), and is accessible under most weather conditions. Gull Island is more remote and accessible only under favorable sea conditions.

Guano harvesting in 1902 would have occurred at Scorpion Rocks shortly after "many" CAAU burrows were first noted in 1895 (Beck 1899). However, guano harvesting in 1912 would have been conducted prior to the documentation of any burrow- or crevicenesting seabird species at Orizaba Rock and Gull Island. ASSP were first reported breeding in crevices at Orizaba Rock in 1937, but CAAU were not reported until 3 nests were found in 1977, apparently in crevices (Hunt et al. 1979). The unusual jagged rock formations on the eastern half of Orizaba Rock may reflect the loss of a deep layer of guano; apparent remnants of a thicker layer of guano also still exist near the peak of the rock, on its west end. At Gull Island about 75 pairs of CAAU were estimated nesting (presumably in crevices) in 1975-1977, along with the one ASSP nest (Hunt et al. 1979). Little or no soil was found on Gull Island in October 1991, although 66 pairs of CAAU using crevices were estimated (Carter et al. 1992, Carter personal observation). Because Gull Island is highly exposed to winter storms, guano may not have built up to a great degree on this rock over time. Orizaba Rock and unharvested areas of Scorpion Rocks are the more likely source(s) of the 1912 guano harvesting.

The loss of the CAAU colony on the main rock at Scorpion Rocks could have occurred 
in 1902 if most of the guano were removed, which could explain why only a few CAAU eggs were collected at Scorpion Rocks (in 1919 and 1929) during the main collecting period in 1928-1941 (Hunt et al. 1979; WFVZ 89785). After 1940, organochlorine pollutants also had impacts on CAAU (Fry 1994, Kiff 1994) and may have caused further declines. In contrast, several specimens of ASSP, Western Gull (Larus occidentalis; WEGU), and Scripps's Murrelets were collected at Scorpion Rocks between 1928 and 1941 (Carter unpublished notes, Hunt et al. 1979). A few CAAU may have remained, continuing to breed on the steep neighboring smaller rock where harvesting presumably did not occur. Some guano also may have been left behind on the main rock, with some subsequently deposited, allowing extensive CAAU burrowing to resume prior to 1976 , the year when 15 burrows were noted (Hunt et al. 1979). CAAU colony growth appeared to continue from 1976 to 1991 when 125 burrows and 17 crevice burrows were counted (Carter et al. 1992). In 1991 many CAAU burrows were in very shallow guano and some may not have had eggs laid in them (Carter personal observation). However, 48 CAAU were captured in mist nets on 2 nights in May 1991 (Carter et al. 1992) and 7 CAAU eggs were collected for studies of organochlorine pollutants in 1992 (Fry 1994, Kiff 1994; VertNet.org). Many burrows appeared to be occupied by CAAU in 1991-1992.

ASSP were probably less affected by guano harvesting at Scorpion Rocks (main rock) than CAAU, with nesting continuing in rock crevices on the inside cliff of the main rock and possibly on the smaller rock and adjacent cliffs on SCZ. In 1928 an ASSP nest was found in a shallow burrow (WFVZ 81574), possibly dug by a few remaining CAAU that mainly bred in crevices on the smaller rocks at that time. Given the captures of many ASSP in mist nets on the main rock in 1991, 1994, and 1997 when no nests were found there, the colony appeared to be almost entirely on the smaller rocks and adjacent cliffs during 1991-1997 (Carter et al. 1992). To what degree guano harvesting may have removed crevice nesting habitat for ASSP on the main rock is unknown, but some reduction likely occurred during this suspected habitat alteration.

We recommend that special geological assessments of the main rock at Scorpion
Rocks, Orizaba Rock, and Gull Island be conducted to confirm whether guano harvesting occurred and to gather baseline data on current guano conditions for future monitoring. If it is confirmed that guano harvesting occurred, artificial habitat for ASSP could be considered in order to replace lost crevice nesting habitat (see McIver et al. 2016, Parker 2016). In addition, new restoration techniques could be developed for replacing large amounts of lost burrow nesting substrate for CAAU. These restoration actions would increase ASSP and CAAU population sizes at SCZ to more closely resemble their estimated historic sizes (if habitat alteration resulted in fewer nesting birds). A similar restoration concept has been suggested for Prince Island (at San Miguel Island), which has also been heavily impacted by extensive guano harvesting as well as damage from military bombing in the past (Whitworth and Carter 2018).

ORGANOCHLORINE POLLUTION.-In 1992, 1996, and 1997, ASSP eggs from Orizaba Rock, Cave of the Birds' Eggs, and Bat Cave had relatively high levels of organochlorine contaminants and eggshell thinning (Fry 1994, Kiff 1994, Carter et al. 2008b). During 1995-1998, relatively low hatching success and many broken eggs during incubation were consistent with the known impacts of organochlorine contaminants (McIver 2002, Carter et al. 2008a, McIver et al. 2016). In the 1960s to the 1980s, much higher organochlorine contaminant concentrations likely occurred in ASSP in the Channel Islands, as was found in Brown Pelicans (Pelecanus occidentalis; BRPE) and Double-crested Cormorants (Phalacrocorax auritus; DCCO) during this period (Risebrough et al. 1971, Gress et al. 1973, Anderson et al. 1975, Gress 1995, MSRP 2005, 2012). Higher pollutant concentrations probably contributed to lower hatching success and thus lower population sizes of ASSP in the Channel Islands in the 1960s to 1980s. While no data are available on contaminant levels before 1992 and hatching success before 1995 in the Channel Islands, the breeding or presence of ASSP was documented at 5 SCZ colonies in the 1960s to 1980s: Cavern Point Cove Caves (1970), Diablo Rocks (1976), Gull Island (1977), Orizaba Rock (1967 and 1976), and Scorpion Rocks (1967). From 1995 to 2011, numbers of nests increased at Cave of the Birds' Eggs, suggesting (in part) the recovery of the population 
(McIver et al. 2016). Larger colony sizes and a wider breeding distribution at SCZ in 1994 compared to the 1970 s also may reflect some recovery from the effects of organochlorine pollution. A much greater survey effort in 1994 seems to best explain why relatively large ASSP colonies were discovered at Bat Cave, Cave of the Birds' Eggs, and Dry Sandy Beach Cave. Similarly, larger numbers of nests at Orizaba Rock in $1995(n=20)$ and $1996(n$ $=27$ ) apparently reflected monthly monitoring, compared to lower numbers found on single surveys in 1976-1977 $(n=8), 1992(n=$ 13), and $1994(n=11)$. At Diablo Rocks similar numbers were found on single surveys in July $1976(n=4)$ and July $1994(n=6)$, indicating little change. Overall, we suspect that population size at SCZ colonies was reduced from the 1950 s to the 1980 s, compared to size observed after 1991 (and estimated historical population sizes at SCZ), but we could not determine by how much and whether any colonies were extirpated during that period.

\section{ACKNOWLEDGMENTS}

Funding for work by Humboldt State University (HSU) on ASSP at SCZ from 1991 to 1998 was provided by the Minerals Management Service (Pacific Outer Continental Shelf Region, Camarillo, CA; Gordon Reetz and Mark Pierson), U.S. Department of Defense (Legacy Resource Management Program and Naval Air Weapons Station, Point Mugu, CA; Tom Keeney, Ron Dow, and Dick Rugen), U.S. Fish and Wildlife Service (Ecological Services, Sacramento, CA; Dan Welsh and Roger Helm), and California Department of Fish and Wildlife (Wildlife Management Division, Sacramento, CA; Esther Burkett and Lyann Comrack). Administrative and in-kind support was provided by HSU (Arcata, CA; Rick Golightly and Jim Hamby); U.S. Fish and Wildlife Service (San Francisco Bay National Wildlife Refuge, Newark, CA; Jean Takekawa); U.S. Fish and Wildlife Service (Northern Prairie Wildlife Research Center), National Biological Service, and U.S. Geological Survey (Dixon, CA; David Gilmer); and Channel Islands National Park (Ventura, CA; Trudy Ingram, Paige Martin, and Kate Faulkner).

HSU field work in 1991-1998 was assisted by Josh Adams, Ed Bailey, John Bulger, Leigh Chan, Doug Cooper, Sharon Dechesne, Sarah
Fangman, Nina Faust, Tonya Fish, Michael Fowlkes, Wendy Fox, John Fries, Ian Gaffney, Jamie Gilardi, David Gilmer, Rick Golightly, Jim Haas, Gretchen Harrington, Sean Hastings, Scott Hatch, Percy Hébert, Roger Helm, Laird Henkel, Robert Holmes, Jim Huckabee, Trudy Ingram, Christine James, Deborah Jory, Nina Karnovsky, John Kelson, Dave Lewis, Irene Manley, Paige Martin, Scott Newman, Peter Ode, Melanie Paquin, Mike Parker, Mark Pierson, Diana Reischel, Dan Richards, Kim Sager, Steve Schwarzbach, Leslie Skelton, Robert Stafford, Chuck Striplen, Craig Strong, Dan Welsh, and Samantha Wisely. Invaluable vessel support was provided from 1991 to 1996 by skipper Dan Christy aboard the F/V Instinct (Instinct Charters, Lake Forest, CA) and from 1996 to 1998 by the Channel Islands National Marine Sanctuary (Santa Barbara, $\mathrm{CA}$ ) aboard the R/V Ballena (skippers John Miller, Ed Cassano, and Steve Beckwith). David Ainley provided a tape of ASSP vocalizations for mist netting in 1991-1997. Shaye Wolf, J. Ross, and Russ Bradley (Point Blue Conservation Science, Petaluma, CA) kindly provided some banding data from Santa Barbara and Southeast Farallon Islands.

Museum specimen information and field notes were obtained largely from the Western Foundation of Vertebrate Zoology, with extensive assistance from Rene Corado. VertNet (vertnet.org) and the staff from many other museums also provided useful specimen information: Melanie Bucci (Museum of Natural History, University of Arizona [UAZ], Tucson, AZ), Krista Fahey (Santa Barbara Museum of Natural History, Santa Barbara, CA), Kimball Garrett (Natural History Museum of Los Angeles County, Los Angeles, CA), Ben Marks (Field Museum of Natural History, Chicago, IL), Mark Robbins (Biodiversity Institute and Natural History Museum, University of Kansas, Lawrence, KS), Gary Shugart (James R. Slater Museum of Natural History, Tacoma, WA), Jeremiah Trimble (Museum of Comparative Zoology, Harvard University, Cambridge, MA), Phil Unitt (San Diego Natural History Museum, San Diego, CA), and Laura Wilkinson (California Academy of Sciences, San Francisco, CA).

\section{Literature Cited}

Adams, J., H.R. Carter, G.J. McChesney, and D.L. WhitworTh. 2016. Occurrence, morphometrics and 
plumage variability among Leach's Storm-Petrels Oceanodroma leucorhoa in the California Channel Islands, 1976-2015. Marine Ornithology 44:113-119.

Ainley, D.G. 1995. Ashy Storm-Petrel (Oceanodroma homochroa). In: A. Poole, editor, The birds of North America online. Cornell Lab of Ornithology, Ithaca, NY. http://bna.birds.cornell.edu/bna/species/185

Ainley, D.G., R.P. Henderson, and C.S. Strong. 1990. Leach's Storm-Petrel and Ashy Storm-Petrel. Pages 128-162 in D.G. Ainley and R.J. Boekelheide, editors, Seabirds of the Farallon Islands: ecology, dynamics, and structure of an upwelling-system community. Stanford University Press, Stanford, CA.

Anderson, D.W., J.R. Jehl JR., R.W. Risebrough, L.A. Woods, L.R. DeWeese, and W.G. Edgecomb. 1975. Brown Pelicans: improved reproduction off the southern California coast. Science 190:806-808.

BECK, R.H. 1899. Additional notes on the birds of Santa Cruz Island, Cal. Bulletin of the Cooper Ornithological Club 1:86-87.

BENT, A.C. 1919. Life histories of North American diving birds. U.S. National Museum Bulletin 107. 245 pp.

BLAKE, E.W., JR. 1887. Summer birds of Santa Cruz Island, California. Auk 4:328-330.

Bunnell, D. 1988. Sea caves of Santa Cruz Island. McNally and Loftin, Santa Barbara, CA. 123 pp.

Carter, H.R., D.G. Ainley, S.G. Wolf, and A.M. WeinSTEIN. 2016a. Range-wide conservation and science of the Ashy Storm-Petrel Oceanodroma homochroa. Marine Ornithology 44:53-62.

Carter, H.R., T.M. DVORAK, and D.L. Whitworth. 2016b. Breeding of the Leach's Storm-Petrel Oceanodroma leucorhoa at Santa Catalina Island, California. Marine Ornithology 44:83-92.

Carter, H.R., G.J. McChesney, D.L. Jaques, C.S. Strong, M.W. Parker, J.E. TakekaWa, D.L. Jory, and D.L. WHITWORTH. 1992. Breeding populations of seabirds in California, 1989-1991. Unpublished draft final report, U.S. Fish and Wildlife Service, Northern Prairie Wildlife Research Center, Dixon, CA.

Carter, H.R., W.R. MCIVER, J. ADAMS, AND J.Y. TAKEKAWA. 2007. Population monitoring of Ashy Storm-Petrels and Cassin's Auklets at Santa Cruz Island, California, in 2006. Unpublished report, Carter Biological Consulting, Victoria, BC; U.S. Fish and Wildlife Service, Ventura, CA; and U.S. Geological Survey, Moss Landing and Vallejo, CA.

Carter, H.R., W.R. MCIver, AND G.J. MCChesney. 2008a. Ashy Storm-Petrel (Oceanodroma homochroa). Pages 117-124 in W.D. Shuford and T. Gardali, editors, California bird species of special concern: a ranked assessment of species, subspecies, and distinct populations of birds of immediate conservation concern in California. Studies in Western Birds 1. Western Field Ornithologists, Camarillo, CA; California Department of Fish and Game, Sacramento, CA.

Carter, H.R., J.L. YeE, D. Welsh, and D.W. Anderson. 2008b. Organochlorine contaminants in Ashy StormPetrel eggs from Santa Cruz Island, California, in 1992-2008: preliminary findings. Unpublished report, Carter Biological Consulting, Victoria, BC; U.S. Geological Survey, Western Ecological Research Center, Sacramento, CA.

Dawson, W.L. 1915. Supposed new records for Santa Cruz Island. Condor 17:203-204.

DeLong, R.L. 1967. Preliminary report, Channel Islands survey, Santa Cruz and Santa Rosa Islands, Eastern
Area Cruise 22 (part), Eastern Area Cruise 23. Unpublished report, Smithsonian Institution, Pacific Ocean Biological Survey, Washington, DC. 3 pp.

DibbleE, T.W. 2001a. Geologic map of western Santa Cruz Island. Dibblee Geological Foundation, Map DF-77, Santa Barbara Museum of Natural History, Santa Barbara, CA.

Dibblee, T.W. 2001b. Geologic map of eastern Santa Cruz Island. Dibblee Geological Foundation, Map DF-78, Santa Barbara Museum of Natural History, Santa Barbara, CA.

FRY, D.M. 1994. Injury of seabirds from DDT and PCB residues in the Southern California Bight ecosystem. Unpublished report, U.S. Fish and Wildlife Service, Ecological Services, Sacramento, CA.

GHERINI, J. 2016. Santa Cruz Island an illustrated history. Volumes 1 and 2. V3 Corporation, Oxnard, CA.

GRess, F. 1995. Organochlorines, eggshell thinning, and productivity relationships in Brown Pelicans breeding in the Southern California Bight. Doctoral dissertation, University of California, Davis, CA.

Gress, F., R.W. Risebrough, D.W. Anderson, L.F. Kiff, AND J.R. JEHL JR. 1973. Reproductive failures of Double-crested Cormorants in southern California and Baja California. Wilson Bulletin 85:197-208.

Harvey, A.L., D.M. Mazurkiewicz, M.W. McKown, K.W. Barnes, and M.W. Parker. 2016. Changing breeding status of the Ashy Storm-Petrel Oceanodroma homochoa on Anacapa Island, California. Marine Ornithology 44:93-97.

Henshaw, H.W. 1876. Appendix H8. Report on the ornithology of the portions of California visited during the field-season of 1875. Pages 224-278 in G.M. Wheeler, editor, Annual report upon the geographical surveys west of the One Hundredth Meridian in California, Nevada, Utah, Colorado, Wyoming, New Mexico, Arizona, and Montana: being Appendix JJ of the Annual Report of the Chief of Engineers for 1876. Government Printing Office, Washington, DC.

Howell, A.B. 1917. Birds of the islands off the coast of southern California. Pacific Coast Avifauna 12:1-127.

Howell, A.B., AND A. van Rossem. 1911. Further notes from Santa Cruz Island. Condor 13:208-210.

Hunt, G.L., Jr., R.L. Pitman, and H.A. Jones. 1980. Distribution and abundance of seabirds breeding on the California Channel Islands. Pages 443-460 in D.M. Power, editor, The California Channel Islands: Proceedings of a Multidisciplinary Symposium, Santa Barbara Museum of Natural History, Santa Barbara, CA.

Hunt, G.L., JR., R.L. Pitman, M. Naughton, K. Winnett, A. Newman, P.R. Kelly, and K.T. Briggs. 1979. Reproductive ecology and foraging habits of breeding seabirds. In: Summary of marine mammal and seabird surveys of the Southern California Bight area. Vol. III - Investigators' Reports. Part III. Seabirds - Book II. Unpublished report, University of California, Santa Cruz, CA.

KIFF, L.F. 1994. Eggshell thinning in birds of the California Channel Islands. Unpublished report, U.S. Fish and Wildlife Service, Ecological Services, Sacramento, CA.

Linton, C.B. 1908. Notes from Santa Cruz Island. Condor 10:124-129.

Mailliard, J. 1899. Spring notes on the birds of Santa Cruz Island, Cal., April, 1898. Bulletin of the Cooper Ornithological Club 1:41-45. 
McIver, W.R. 2002. Breeding phenology and reproductive success of Ashy Storm-Petrels (Oceanodroma homochroa) at Santa Cruz Island, California, 1995-98. Master's thesis, Department of Wildlife, Humboldt State University, Arcata, CA.

McIver, W.R., H.R. Carter, R.T. Golightly, G.J. McChesney, D. Welsh, and A.L. HaRvey. 2009. Reproductive performance of Ashy Storm-Petrels (Oceanodroma homochroa) at Santa Cruz Island, California, in 1995-2007. Pages 269-281 in C.C. Damiani and D.K. Garcelon, editors, Proceedings of the Seventh California Islands Symposium, Oxnard, California, February 5-8, 2008. Institute for Wildlife Studies, Arcata, CA.

McIver, W.R., H.R. Carter, A.L. Harvey, D.M. MaZurkiewicz, J.A. Howard, P.L. Martin, and J.W. MASON. 2018. Avian and skunk predation of Ashy Storm-Petrels at Santa Cruz Island, California. Western North American Naturalist 78:421-440.

McIver, W.R., H.R. Carter, A.L. Harvey, D.M. MAZURKIEWICZ, AND J.W. MASON. 2016. Use of social attraction to restore Ashy Storm-Petrels Oceanodroma homochroa at Orizaba Rock, Santa Cruz Island, California. Marine Ornithology 44:99-112.

[MSRP] Montrose Settlements Restoration Program. 2005. Final restoration plan and programmatic environmental impact statement/environmental impact report. Montrose Settlements Restoration Program, National Oceanic and Atmospheric Administration, U.S. Fish and Wildlife Service, National Park Service, California Department of Fish and Game, California Department of Parks and Recreation, and California State Lands Commission, Long Beach, CA. http://www.gc.noaa.gov/gc-rp/msrpfinalrestora tionplan.pdf

[MSRP] Montrose Settlements Restoration Program. 2012. Final phase 2 restoration plan and environmental assessment/initial study. Montrose Settlements Restoration Program, National Oceanic and Atmospheric Administration, U.S. Fish and Wildlife Service, National Park Service, California Department of Fish and Game, California Department of Parks and Recreation, and California State Lands Commission, Long Beach, CA. http://www.mont roserestoration.noaa.gov/wp-content/uploads/2012/ 08/Final-MSRP-RP-EA-IS-6-26-12.pdf
Parker, M.W. 2016. Conservation action plan for Ashy Storm-Petrels (Oceanodroma homochroa) in California and Baja California. Unpublished report, California Institute of Environmental Studies, Davis, CA.

Risebrough, R.W., F.C. Sibley, and M.N. Kirven. 1971. Reproductive failure of the Brown Pelican on Anacapa Island in 1969. American Birds 25:8-9.

Sowls, A.L., A.R. DeGange, J.W. Nelson, and G.S. LESTER. 1980. Catalog of California seabird colonies. U.S. Fish and Wildlife Service, Biological Services Program. FWS/OBS-80/37.

Streator, C.P. 1886. List of birds in the vicinity of Santa Barbara, Cal., during the year 1885. Ornithologist and Oologist 11:51-52; 66-67.

Townsend, C.H. 1890. Birds from the coasts of western North America and adjacent islands, collected in 1988-'89, with descriptions of new species. Proceedings of the U.S. National Museum 13:131-142.

Whitworth, D.L., and H.R. Carter. 2018. Scripps's Murrelet at San Miguel Island, California: status of a small population at the northwest limit of the breeding range. Western North American Naturalist 78: $441-456$.

Whitworth, D.L., H.R. Carter, T.M. Dvorak, L.S. FARLEY, AND J. King. 2014. Status, distribution, and conservation of the Scripps's Murrelet at Santa Catalina Island, California. Monographs of the Western North American Naturalist 7:321-338.

Willett, G. 1910. A summer trip to the northern Santa Barbara Islands. Condor 12:170-174.

Wright, H. 1913. Note on the Ashy Petrel. Condor 15: 229.

Wright, H., AND G.K. SNyder. 1913. Birds observed in the summer of 1912 among the Santa Barbara Islands. Condor 15:86-92.

Wright, W.W., Jr., R.S. Wright, and J.M. Wright. No date. History of Siwash. Unpublished manuscript available at Santa Cruz Island Foundation, Carpinteria, CA.

Received 23 January 2017 Revised 19 November 2017 Accepted 12 January 2018 Published online 19 October 2018 